\title{
Impact on sediment yield due to the intensification of tobacco production in a catchment in Southern Brazil.
}

\author{
Impacto na produção de sedimentos devido à intensificação da produção de tabaco em uma \\ bacia no sul do Brasil.
}

\author{
Gustavo Henrique Merten ${ }^{1}$ Jean Paolo Gomes Minella ${ }^{2}$
}

\section{ABSTRACT}

Tobacco production in Southern Brazil has caused a profound impact in the environment, resulting in heavy sediment yields and diminishing water quality. Public programmes have attempted to address these problems by encouraging the implementation of erosion control practices. To evaluate the impact of these programmes, a small rural catchment $\left(1.33 \mathrm{~km}^{2}\right)$ in Arvorezinha county, in the state of Rio Grande do Sul, Brazil, has been monitored since 2001. Instruments to automatically monitor flow rate and precipitation were installed in the catchment and sediment has been measured manually using a DH-48 sampler. Despite lower rainfall in 2003 , there was a significant increase in the frequency of low and average flow rates, and sediment yield increased $25 \%$ in $2003\left(91 \mathrm{Mg} \mathrm{km}^{-2}\right.$ year $\left.^{-1}\right)$, compared with $2002\left(73 \mathrm{Mg} \mathrm{km}^{-2}\right.$ year $\left.{ }^{-1}\right)$. These results can be explained by a $37.7 \%$ increase in the area dedicated to tobacco cultivation in 2003, due to a rise in tobacco prices.

Key words: erosion; catchment monitoring.

RESUMO

A produção de fumo no sul do Brasil tem causado um profundo impacto no meio ambiente, resultando em alta de produção de sedimentos e diminuindo a qualidade da água. Programas públicos têm se esforçado para resolver estes problemas com a implementação de práticas de controle de erosão. Para avaliar o impacto destes programas, uma pequena bacia rural $\left(1,33 \mathrm{~km}^{2}\right)$ em Arvorezinha, no estado do Rio Grande do Sul, tem sido monitorada desde 2001. Instrumentos automáticos de medição da vazão e precipitação foram instalados na bacia e os sedimentos foram medidos com um amostrador manual do tipo DH48. Apesar de ter chovido menos em 2003, houve um aumento significativo na freqüência das vazões de estiagem e médias, e um aumento de $25 \%$ na produção de sedimentos em $2003\left(91 \mathrm{Mg} \mathrm{km}^{-2}\right.$ year-1) comparado com 2002 ( $73 \mathrm{Mg} \mathrm{km}^{-2}$ year $\left.^{-1}\right)$. Estes resultados podem ser explicados por um aumento de $37,7 \%$ na área dedicada ao cultivo de fumo em 2003, devido ao aumento no preço do fumo.

Palavras-chave: erosão, monitoramento de bacias.

Most of the tobacco in Southern Brazil is produced in small farms on land with low agricultural potential. Steep hillsides, combined with traditional cultivation practices, have caused rapid degradation of natural resources, contributing to a worsening of the cycle of poverty. Traditional cultivation practices are characterized by the use of draft animals to till the soil prior to transplant tobacco seedlings. There is no soil conservation practices and an excessive use of agrochemicals. In addition, the period of greatest rainfall erosivity coincides with the beginning of the planting cycle, when soil cover is minimal (SILVA, 2004). This combination of factors favours runoff erosion and the transfer of sediment to rivers. This sediment, in turn,

\footnotetext{
${ }^{1}$ Instituto de Pesquisas Hidráulicas da Universidade Federal do Rio Grande do Sul (UFRGS), Av. Bento Gonçalves, 9500, 90650-001, Porto Alegre, RS, Brasil. Fone: 05133167513. E-mail: merten@iph.ufrgs.br. Autor para correspondência

${ }^{2}$ Programa de Pós-graduação em Recursos Hídricos e Saneamento Ambiental, Instituto de Pesquisas Hidráulicas da UFRGS, Av. Bento Gonçalves, 9500, 90650-001, Porto Alegre, RS, Brasil; tel: 05133166325. E-mail: jminella@ppgiph.ufrgs.br
} 
causes river siltation and a reduction in water quality due to the agricultural chemicals and nutrients transported by sediment (MERTEN \& MINELLA, 2005). Longer-term investigations of British rivers shows evidence of increases in the nutrient content of sediment deposited in the flood plain store (WALLING, 1999). In an effort to attenuate this situation in southern Brazil, the government has implemented programmes that include the introduction of soil conservation practices, with the goal of reducing erosion rates (SAA, 1999). To evaluate the effectiveness of these programmes, an environmental monitoring project was initiated in 2001 to quantify the impact of the conservation practices on soil quality, the hydrosedimentological regime, and water quality, in a small rural catchment. In 2003, a 20\% increase in the price of tobacco stimulated an expansion of the cultivated area, with results measurable through the monitoring programme. This study presents the monitoring results, showing the link between sediment yield and land-use pressure, triggered by economic factors.

The catchment being monitored measures $1.33 \mathrm{~km}^{2}$ and includes the headwaters of the Lajeado Ferreira Stream, a small tributary of the Guaporé River located in Arvorezinha county, state of Rio Grande do Sul. Altitude varies between 560 and $740 \mathrm{~m}$. The geology is predominantly basalt, with rolling terrain in the upper portion (7\% average slope), and steeply rolling terrain, characterized by short slopes and box canyons, in the lower two-thirds. Average channel slope is $9 \%$, with runoff concentration time varying between 20 and 50 min. Predominant soils are Inceptisols and Entisols. Average annual precipitation is $1605 \mathrm{~mm}$. Socioeconomic indicators classify the region as possessing one of the highest indices of rural poverty in the state of Rio Grande do Sul.

To evaluate the hydrological and sedimentological variables of the catchment, an automatic meteorological station, four raingauges, and a Parshall flume with an automatic water level sensor were installed. The rate of suspended sediment discharge was determined indirectly using US DH-48 and Single Stage sampler (CARVALHO, 1994). Transport of suspended sediment only occurs during rainstorms, so the frequency of sediment sampling corresponds with the majority of these events. Sediment yield was calculated based on the sampled events, using hydrographs and sedimentographs. Changes in soil use were determined by field surveys, assisted by a GPS with Spring/INPE ${ }^{\circledR}$ software. Principal soil uses in the catchment consist of cultivated tobacco fields, pasture, fallow, and forest. Fields showing signs of reduced productivity typically are left fallow for at least two years. The category forest includes areas of native forest, trees planted to supply firewood for drying tobacco, and riparian zones.

Significant changes in soil use were measured in the catchment during 2003. A 37.7\% increase in cultivated area occurred at the expense of other soil uses, especially forested areas, which were reduced in $19.9 \%$. Of special note, riparian vegetation was diminished by $10 \%$. It increased the sediment transfer from the hillslopes to the channel, as riparian vegetation plays a key role in retaining sediment. A second aspect was a drastic change in lowland area. Many lowlands adjacent to the Lajeado Ferreira Stream were drained during the first half of 2003 and put into cultivation, thus contributing to an increase in surface runoff and the creation of new sediment sources. In 2002, the frequency of low flows $\left(<2.9 \mathrm{~L} \mathrm{~s}^{-1}\right)$ was $1.6 \%$, while in 2003 it increased to $36 \%$. At the same time, floods of much greater intensity were observed in 2003.

The expansion of the area under tobacco cultivation that occurred in 2003 significantly altered the sediment balance for the catchment. This was registered by increases in the frequency of higher suspended sediment concentrations and in increasing sediment yield. A comparison between 2002 and 2003 clearly indicates that in 2003 there was a greater frequency of concentrations greater than $600 \mathrm{mg} \mathrm{L}^{-1}$, whereas in 2002, concentrations of less than $450 \mathrm{mg} \mathrm{L}^{-1}$ predominated (Figure 1).

The average flow rate and precipitation in 2003 were slightly lower than in 2002; however, there were flow spikes of up to 6000 $\mathrm{L} \mathrm{s}^{-1}$ during 2003, whereas in 2002, the highest flow rate did not exceed 1200 s s (Table 1). This fact is certainly associated with wetland drainage and with the larger area of soil exposed during field preparation.

Values for precipitation, erosivity, flow rate, and sediment yield were grouped according to the different activities involved in tobacco production (Table 1). Sediment yield in $2003\left(91 \mathrm{Mg} \mathrm{km}^{-2}\right.$ year $\left.^{-1}\right)$ was $25 \%$ higher than in $2002\left(73 \mathrm{Mg} \mathrm{km}^{-2}\right.$ year $^{-1}$ ) (Table 1$)$. During the period from July to October alone, sediment yield for 2003 approximated the total yearly yield for 2002. It is interesting to note that $80 \%$ of the sediment yield for 2003 occurred during three rainfall events registered in July. This was due to the presence of countless newly worked areas, especially in the headwaters of the Lajeado Ferreira Stream, in which riparian vegetation had been removed, as well as to the presence of large quantities of sediment deposited next to the stream channel as a result of wetland drainage. It is also worth noting that the sediment yield values for 


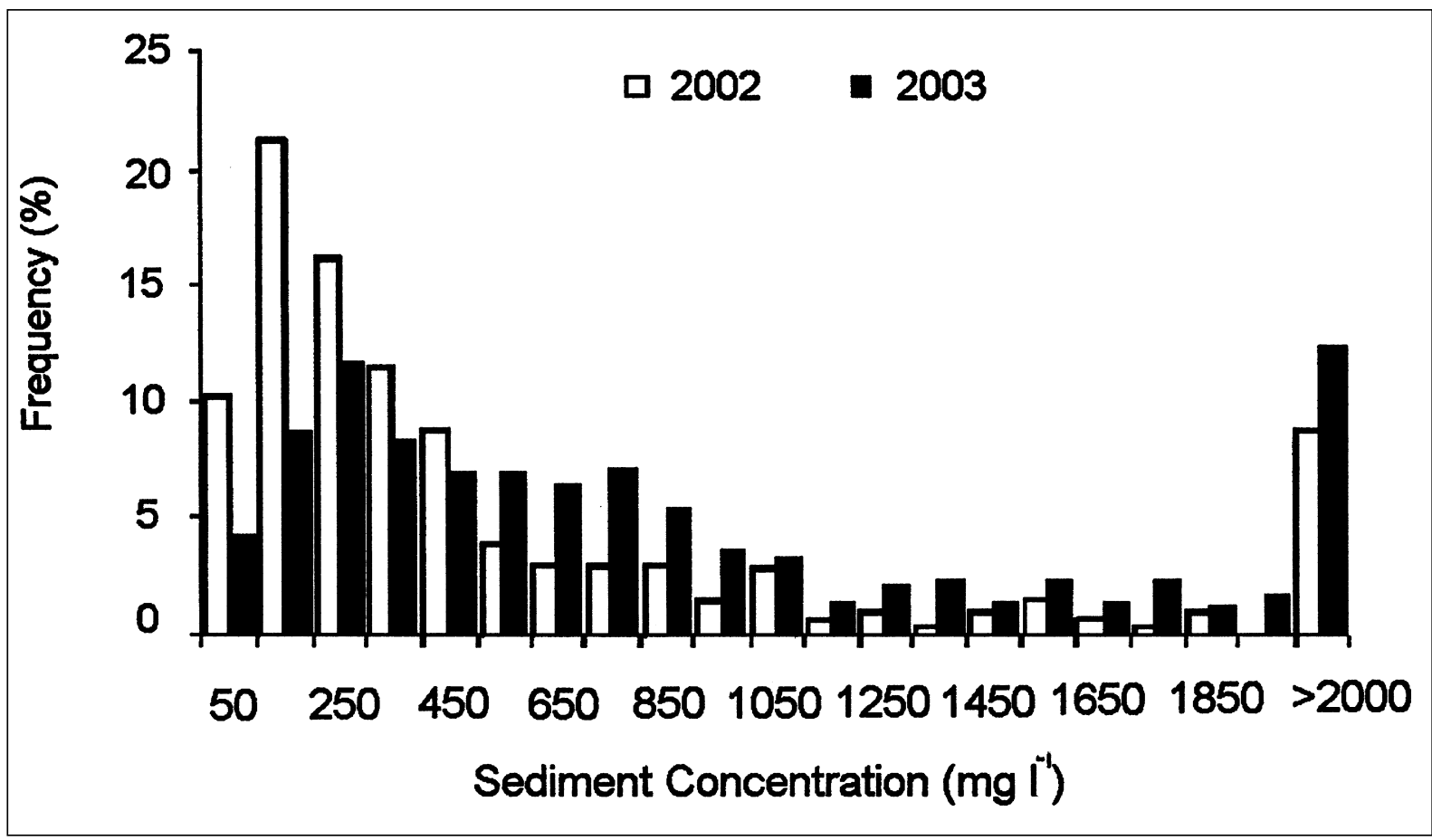

Figure 1 - Frequency histogra of suspended sediment concentration for the Arvorezinha catchment during the two monitoring periods.

the catchment are much higher than those found during a 1998 survey of principal Brazilian rivers, in which the sediment yield for the middle section of the Guaporé River was estimated at around $23 \mathrm{Mg} \mathrm{km}^{-2}$ year-1 (ELETROBRÁS, 1998).

In field surveys carried out after the events, many gullies were observed in the steeper areas where runoff erosion was more severe, as well as a striking change in the morphology of the stream channel due to sediment deposition. It is likely that these deposits will constitute an important sediment source during the next few years, contributing significantly to the catchment's sediment yield.
Based on the monitoring results of the hydrological and sedimentological characteristics of the Lajeado Ferreira Stream, it was possible to conclude that the shift to more intensive tobacco production in ecologically-fragile areas, such as wetlands, riparian zones, and steep slopes, resulted in severe impacts on the hydrological system and sediment yield. Given that tobacco is grown by very poor farmers on marginal lands, the economic stimulus represented by a price increase can greatly accelerate the process of environmental degradation, unless accompanied by an equal or greater stimulus to implement adequate environmental protection, especially improved soil management practices.

Table 1 - Precipitation, erosivity, average flow rate, number of measured events and sediment yield for the Lajeado Ferreira Stream catchment.

\begin{tabular}{|c|c|c|c|c|c|c|c|c|c|c|}
\hline \multirow[t]{2}{*}{ Variables } & \multicolumn{2}{|c|}{ Jan.-Mar. } & \multicolumn{2}{|c|}{ Apr.-Jun. } & \multicolumn{2}{|c|}{ Jul.-Oct. } & \multicolumn{2}{|c|}{ Nov.-Dec. } & \multicolumn{2}{|c|}{ Year } \\
\hline & 2002 & 2003 & 2002 & 2003 & 2002 & 2003 & 2002 & 2003 & 2002 & 2003 \\
\hline $\mathrm{P}$ & 210.5 & 410.1 & 680.8 & 429.0 & 867.7 & 585.5 & 460.6 & 410.7 & 2219.6 & 1835.3 \\
\hline $\mathrm{E}$ & 443.5 & 1280.7 & 3016.9 & 1449.7 & 3798.9 & 2404.3 & 2046.3 & 1868.4 & 9305.6 & 7002.8 \\
\hline $\mathrm{Q}$ & 9.0 & 17.3 & 44.2 & 33.5 & 65.3 & 33.7 & 55.9 & 25.7 & 43.6 & 27.6 \\
\hline $\mathrm{Ne}$ & 0 & 3.0 & 5.0 & 2.0 & 11.0 & 4.0 & 0 & 2.0 & 16.0 & 11.0 \\
\hline SY & 0 & 7.25 & 20.79 & 8.53 & 52.15 & 70.53 & 0 & 4.83 & 72.94 & 91.14 \\
\hline
\end{tabular}

$\mathrm{P}$, precipitation (mm); E, erosivity (MJ mm ha $\left.{ }^{-1} \mathrm{~h}^{-1} \mathrm{month}^{-1}\right)$; $\mathrm{Q}$, average flow rate ( $\left.\mathrm{L} \mathrm{s}^{-1}\right)$; Ne, number of measured events; SY, sediment yield $\left(\mathrm{Mg} \mathrm{km}^{-2}\right)$. 


\section{REFERENCES}

CARVALHO, N.O. Hidrossedimentologia prática. Rio de Janeiro: CPRM, Eletrobrás, 1994. 371p.

ELETROBRÁS. Diagnóstico das condições sedimentológicas dos principais rios no Brasil. Rio de Janeiro: ELETROBRÁS, 1998. 83p.

MERTEN， G.H.; MINELLA， J.P.G. Monitoramento hidrossedimentométrico e da qualidade de água da microbacia de Arvorezinha: subprojeto 7 do Projeto de Monitoramento Ambiental de Microbacias Hidrográficas do Programa RS-Rural. Porto Alegre: IPH-UFRGS, 2005. 62p. (Boletim Técnico).

SAA SECRETARIA DA AGRICULTURA E DO ABASTECIMENTO. Manual de operação: estrutura and manejo. Porto Alegre: Secretaria da Agricultura e Abastecimento, 1999. 56p. (Boletim Técnico, 1).

SILVA, A.M. da. Rainfall erosivity map for Brazil. Catena, v.57, p.251-259, 2004.

WALLING, D.E. Linking land use, erosion and sediment yields in river basins. Hydrobiologia v.410, p.223-240, 1999. 